\title{
Processing, nutritional composition and health benefits of finger millet in sub-saharan Africa
}

\author{
Shonisani Eugenia RAMASHIA ${ }^{1 *}$, Tonna Ashim ANYASI ${ }^{1}$, Eastonce Tend GWATA ${ }^{2}$, \\ Stephen MEDDOWS-TAYLOR ${ }^{3}$, Afam Israel Obiefuna JIDEANI ${ }^{1}$ (D)
}

\begin{abstract}
Finger millet (Eleusine coracana) also known as tamba, is a staple cereal grain in some parts of the world with low income population. The grain is characterized by variations in colour (brown, white and light brown cultivars); high concentration of carbohydrates, dietary fibre, phytochemicals and essential amino acids; presence of essential minerals; as well as a gluten-free status. Finger millet (FM) in terms of nutritional composition, ranks higher than other cereal grains, though the grain is extremely neglected and widely underutilized. Nutritional configuration of FM contributes to reduced risk of diabetes mellitus, high blood pressure and gastro-intestinal tract disorder when absorbed in the body. Utilization of the grain therefore involves traditional and other processing methods such as soaking, malting, cooking, fermentation, popping and radiation. These processes are utilised to improve the dietetic and sensory properties of FM and equally assist in the reduction of anti-nutritional and inhibitory activities of phenols, phytic acids and tannins. However, with little research and innovation on FM as compared to conventional cereals, there is the need for further studies on processing methods, nutritional composition, health benefits and valorization with a view to commercialization of FM grains.
\end{abstract}

Keywords: finger millet; nutritional composition; gluten-free; antioxidant properties; traditional processing; value-added products.

Practical Application: Effects of processing on nutritional composition, health benefits and valorization of finger millet grains.

\section{Introduction}

The term millet is derived from the French word "mille" which means thousand, with a handful of millet containing up to 1000 grains (Shahidi \& Chandrasekara, 2013). Millet belongs to the group of small-seeded species of cereal crops or grains which are annual plants (Shiihii et al., 2011). Finger millet, a member of the millet group and also known as ragi or tamba (Jideani et al., 1996; Ramashia et al., 2018) is so called due to its growth form of panicles which takes the form of several fingers (Sood et al., 2017). The grain belongs to the family Poaceae which originated in Ethiopia and the sub-family Chloridodeae (Pradeep \& Sreerama, 2015; Sood et al., 2016; Ramashia et al., 2018). Different cultivars of FM grain exist: brown, light brown and white (Devi et al., 2014; Kumar et al., 2016), with grain colour used as the distinct means of cultivar differentiation. The white cultivars have been developed mainly for the baking industry, the brown and light brown types used for porridge while the brown cultivar is utilised for brewing traditional opaque beer in Southern Africa (Sood et al., 2017).

The grain is a semi-arid region crop cultivated in dry areas with limited rainfall and can adapt to various agro-climatic conditions (Gull et al., 2014). Period of cultivation of the grain is February and August with the period of harvest set in June or
January. Finger millet grains are cultivated in Nepal (Adhikari, 2012; Jideani, 2012), Sri Lanka, Bhutan and the Himalayan regions of India. The grain is also cultivated in Taiwan, China, Japan (to a limited extent), as well as in South Carolina in the United States (Mathur, 2012). About 55-60\% of globally produced FM is cultivated in Africa (Dlamini \& Siwela, 2015), mainly in Ethiopia, Kenya, Nigeria, Malawi, Tanzania, Uganda, Zambia and Zimbabwe (Mathur, 2012). The grain is widely cultivated in Africa using different names (Table 1). The total annual production of all millets worldwide is approximately 4.5-5 million tons (Table 2 ), with India alone producing about 2.5 million tons and some countries in Africa accounting for about 2 million tons of the grains (Mathur, 2012). India is thus reported to be the largest producer of FM (Wankhede et al., 1979; Pandhre et al., 2011), contributing a total of $60 \%$ of the global production (Gull et al., 2014). Apart from India being its largest producer, FM is the oldest cultivated cereal crop in India and is referred to as "nrttakondaka", although also named "rajika" or "markataka" which means dancing grain (Shobana et al., 2013). In terms of production in the semi-arid regions, FM ranks fourth after sorghum, pearl millet and foxtail millet respectively (Shiihii et al., 2011; Mathur, 2012). 
Table 1. Common names of finger millet (Eleusine coracana).

\begin{tabular}{lll}
\hline \multicolumn{1}{c}{ Country } & \multicolumn{1}{c}{ Common names } & \multicolumn{1}{c}{ References } \\
\hline Uganda & Bulo, ragi and wimbi. & Shimelis et al. (2009), Blench (2012), Emmambux \& Taylor (2013). \\
Nigeria & Tamba, pwana and sarga. & Jideani et al. (1996), Shiihii et al. (2011), Blench (2012). \\
Swahili & Wimbi and ulezi. & Shimelis et al. (2009). \\
Zimbabwe & Poko, rapoho, zviyo, njera, uphoko, ruweza and mazhovole. & Singh \& Raghuvanshi (2012). \\
Zambia & Lupoko, mawele, amale, bule, kambale, majolothi and bulo. & Singh \& Raghuvanshi (2012), Blench (2012). \\
South Africa & Mufhoho (Venda), & Blench (2012). \\
& Uphoko (IsiZulu), osgras (Afrikaans), mpogo (Pedi), majolothi & van Wyk \& Gericke (2018). \\
& (Ndebele). & \\
Kenya & Wimbi and mugimbi. & Mathur (2012), Singh \& Raghuvanshi (2012). \\
Ethiopia & Takuso, gadussa, dzoko and barankiya. & Blench (2012), Singh \& Raghuvanshi (2012). \\
Tanzania & Mwirubi, mbege and dègi. & Mathur (2012), Shobana et al. (2013). \\
Chad & Sarga. & Blench (2012). \\
Malawi & Poko, hawere, lipoke, usanje, khawke, malesi, mulirubi, lupodo, & Blench (2012), Mathur (2012), Shobana et al. (2013). \\
& mawe and dègi. & \\
Boutu & Bale. & Mathur (2012). \\
Sudan & Telebun, akima, bek, mataighio and kal. & Shimelis et al. (2009), Blench (2012). \\
\hline
\end{tabular}

Table 2. African countries that produce millet grains in thousands per tons from 2010-2014.

\begin{tabular}{|c|c|c|c|c|c|}
\hline Country & 2010 & 2011 & 2012 & 2013 & 2014 \\
\hline Nigeria & 5170430 & 2711000 & 5000000 & 5000000 & 1384900 \\
\hline Burkina Faso & 1147894 & 828741 & 1078374 & 1109000 & 972339 \\
\hline Uganda & 267973 & 292000 & 244000 & 228000 & 237000 \\
\hline Senegal & 813295 & 480759 & 661673 & 572155 & 408993 \\
\hline Ethiopia & 634826 & 651851 & 742297 & 807056 & 128344 \\
\hline Ghana & 218952 & 183922 & 179684 & 200000 & 155000 \\
\hline Zimbabwe & 50999 & 60000 & 44000 & 55000 & 88000 \\
\hline South Africa & 6900 & 7000 & 6500 & 6700 & 6340 \\
\hline Mozambique & 48699 & 51602 & 47000 & 48000 & 29332 \\
\hline
\end{tabular}

Source: Food and Agricultural Organisation (2016).

Finger millet grains are gluten-free, non-acid-forming (Muthamilarasan et al., 2016), easy to digest with low glycemic index foods (Manjula \& Visvanathan, 2014). Its low glycemic index food property is reported to be a good choice for people with celiac disease (disease caused by gluten-containing cereal protein ingestion) and diabetes as consumption of the grain assist in the regulation of blood glucose level (Jideani \& Jideani, 2011). The grains consist of nutrients: dietary fibre, carbohydrates, iron and calcium in high concentration when compared to other cereal grains (Sood et al., 2016). Finger millet grains also contain high amount of magnesium and phosphorus. Absorption and utilization of these nutrients in the human body contributes to the reduction of chronic diseases such as lowering of high blood pressure, ischemic strokes, cardiovascular diseases, cancers, obesity and type II diabetes (Kaur et al., 2014; Ramashia et al., 2018). Krishnan et al. (2012) reported that FM grains contain polyphenols and phytates which are known to influence the availability of minerals.

Processing of FM grains comprises both the traditional and modern methods. The traditional method of processing can be employed in the manufacture of value-added products such as soaked, cooked, malted, papad, fermented, popped or puffed, extruded and multi-grain flour (Sood et al., 2017). Traditional method of FM processing also includes a method of spreading and drying the grains in the sun for a period of one week. Upon drying, the grains are stored in a bag and later used for the processing and manufacture of different food products (Young, 1999). Dried FM grains can be stored for more than 5-10 y, but a major hurdle is that the grains are very tiny and not easy to handle. The grains are resistant to diseases and insects but are easily invaded by fungal disease (Usai et al., 2013; Sood et al., 2016). Despite its usefulness and health beneficial properties, there is little research and innovation on FM grains/ flours as compared to conventional cereal grains such as maize, sorghum, rice and wheat. This study therefore reviews the processing, nutritional and health benefits of FM as well as its use in value-added products.

\section{Structure of finger millet grains}

Finger millet grains are globular in shape and its diameter varies from 1.0 to $1.5 \mathrm{~mm}$ (Siwela, 2009; Gull et al., 2014). The predominant cultivar of FM grains is the brown (purna) cultivar, with few varieties occurring as white (hamsa) (Wankhede et al., 1979; Vadivoo et al., 1998; Ramashia, 2018) and red cultivars (Emmambux \& Taylor, 2013). Sood et al. (2017) reported that FM grains consist of a unique grain characteristic of an utricle 
instead of a true caryopsis, thus making the pericarp not to be completely fused with the testa. Similarly, the structure of other millets such as pearl, foxtail, fonio and teff millet are regarded as caryopses. The term caryopses refers to a single-seeded fruit in which the fruit coat or pericarp surrounds the grain, adheres tightly to the grain coat (Wrigley \& Batey, 2010) and has a brick red-coloured seed coat (Patel et al., 2014).

The uniqueness of FM grain imparts a characteristic of allowing the pericarp to be easily removed upon rubbing the grains with mortar and pestle. Another unique structural characteristic of FM grain is its five (5) layered-testa which has been implicated as one of the likely reasons for the presence of a high dietary fibre content in the grain (Shobana et al., 2013). The principal anatomical parts of the FM grains are pericarp, germ and the endosperm (Figure 1). The pericarp is an outer thin layer which covers the grain and it is known as the glume. The grain pericarp consist of three (3) layers with varying thickness: the epicarp (outermost layer), mesocarp (middle layer) and endocarp (inner layer) (Siwela, 2009; Wrigley \& Batey, 2010; Ramashia, 2018).

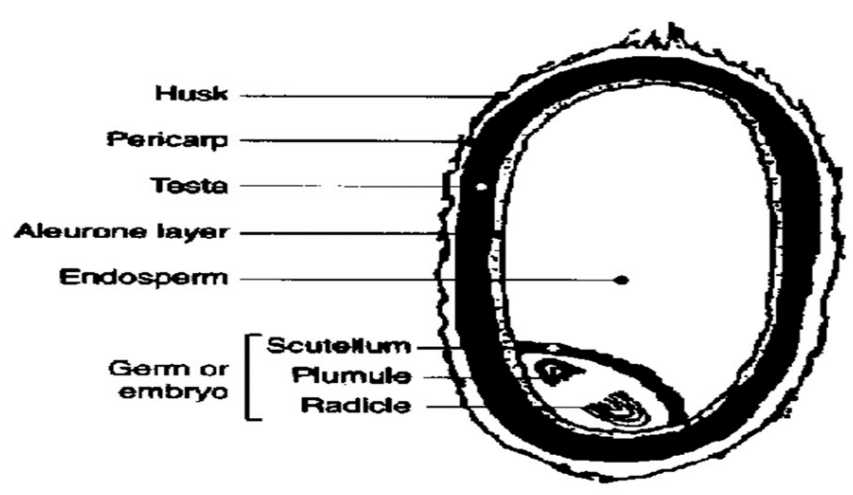

Figure 1. Structure of finger millet grain. Source: Ramashia (2018).
Prior to further processing, the pericarp is removed from the kernel because it is a non-edible tissue (Patel \& Verma, 2015). The endosperm forms the largest anatomical component of the kernel. Endosperm is attached to the seed coat and is used in the production of flour (Palanisamy et al., 2012).

\section{Nutritional, antioxidant properties and potential health benefits of finger millet grains}

Finger millet grains are said to contain essential minerals such as calcium $(\mathrm{Ca})$ and phosphorus $(\mathrm{P})$. The grains contain the highest amount of $\mathrm{Ca}$, ranging from 162.0-358.0 mg/100 g when compared to other millet species (Roopa \& Premavalli, 2008; Manjula et al., 2015). Calcium which is predominantly present in FM, plays an essential role in growing children, pregnant women, the elderly (Jideani, 2012; Chappalwar et al., 2013) as well as in people suffering from obesity, diabetes and malnutrition (Jayasinghe et al., 2013; Manjula et al., 2015). Deficiency of $\mathrm{Ca}$ in the body can be mitigated by consuming FM food products in the daily diet of both young and elderly people (Towo et al., 2006). Phosphorus, another mineral present in FM, contributes to the development of body tissue and energy metabolism (Vanithasri et al., 2012; Ramashia et al., 2018), with concentration of $\mathrm{P}$ in FM ranging from 130.0-283.0 mg/g. Other minerals present in FM grains include iron with a concentration of 3-20\% (Rajiv et al., 2011; Shukla \& Srivastava, 2014) and magnesium implicated for the reduction of high blood pressure, severity of asthma, frequency of migraines and the risk of heart attack (Saleh et al., 2013; Verma \& Patel, 2013; Prashantha \& Muralikrishna, 2014). In comparison with other millet species, FM grains are more nutritious (Upadhyaya et al., 2011; Adhikari, 2012; Shobana et al., 2013; Devi et al., 2014; Dlamini \& Siwela, 2015), with higher mineral content and proximate composition (Table 3), though the grain is still extremely neglected and widely underutilized (Roopa \& Premavalli, 2008).

Table 3. Proximate composition and mineral contents of millet species.

\begin{tabular}{|c|c|c|c|c|c|}
\hline Nutrients & Foxtail millet & Kodo millet & Barnyard millet & Pearl millet & Finger millet \\
\hline \multicolumn{6}{|c|}{ Proximate composition $(\mathrm{g} / 100 \mathrm{~g})$} \\
\hline Moisture & 11.2 & 12.8 & 11.9 & 12.4 & $7.15-13.1$ \\
\hline Protein & $11.50-12.3$ & 9.8 & 6.2 & $11.6-11.8$ & 7.7 \\
\hline Fat/ lipids & $2.38-4.3$ & 1.3 & 2.2 & $4.8-5.0$ & 1.8 \\
\hline Minerals & $0.47-3.3$ & 2.6 & 4.4 & $2.2-2.3$ & 2.7 \\
\hline Dietary fiber & $2.5-8.5$ & 2.47 & 1.98 & 11.3 & $15-22.0$ \\
\hline Carbohydrates & $60.9-75.2$ & $65.9-66.6$ & 65.5 & $67-67.5$ & $75.0-83.3$ \\
\hline Energy (kcal) & 331 & 309 & 307 & $361-363$ & \\
\hline \multicolumn{6}{|c|}{ Minerals (mg/ $100 \mathrm{~g})$} \\
\hline Phosphorus & 290 & 188 & 280 & 296 & $130-250.0$ \\
\hline Potassium & 250 & 144 & - & 307 & $430-490$ \\
\hline Magnesium & 81 & $147-228$ & 82 & 137 & $78-201$ \\
\hline Calcium & 31 & 27 & $20-22$ & 42 & 398.0 \\
\hline Sodium & 4.6 & 4.6 & - & 10.9 & 49.0 \\
\hline Zinc & 2.4 & 0.7 & 3.0 & 3.1 & 2.3 \\
\hline Iron & 2.8 & $0.5-5.0$ & $5.0-18.6$ & 8.0 & $3.3-14.89$ \\
\hline Manganese & 0.60 & $1.10-3.3$ & 0.96 & 1.15 & $17.61-48.43$ \\
\hline Copper & 2.4 & 1.60 & 0.60 & 1.06 & 0.47 \\
\hline
\end{tabular}

Sources: Shimelis et al. (2009), Siwela (2009), Singh \& Raghuvanshi (2012), Amadou et al. (2013), Saleh et al. (2013), Shobana et al. (2013), Verma \& Patel (2013), Patel et al. (2014), Muthamilarasan et al. (2016), Ramashia (2018). 
Vitamins which are other nutrients present in FM grains are important micronutrients required by the human body for normal growth and self-maintenance. Vitamins are grouped into categories such as fat and water-soluble vitamins and a lack of vitamins may lead to vitamin deficiencies which can cause health problems (Ottaway, 2008; Dionex Corporation, 2010). Finger millet grains possess fat and water-soluble vitamins and are rich in vitamins A and B complex (Table 4) (Chappalwar et al., 2013; Devi et al., 2014). However, vitamin $C$ is absent in the dried grain (Siwela, 2009). Finger millet grains contain $44.7 \%$ of essential amino acids (Singh \& Raghuvanshi, 2012) including methionine, cysteine and tryptophan (Jideani, 2012; Manjula et al., 2015; Ramashia et al., 2018), lysine (Mamatha \& Begum, 2013); isoleucine, leucine and phenylalanine (Sood et al., 2017) as well as threonine (Table 5) which helps to lower cholesterol levels and reduce risk of cancer and obesity in the human body (Mathanghi \& Sudha, 2012; Thapliyal \& Singh, 2015). The grains contain the highest amount of methionine $(194 \mathrm{mg} / \mathrm{g})$ when compared to other millet species (Singh et al., 2012; Prashantha \& Muralikrishna, 2014).

Finger millet grains also contain essential fatty acids such as linolenic and palmitic acids which are essential for the development of brain and neural tissue (Kunyanga et al., 2013; Muthamilarasan et al., 2016). Fat which contributes to better storage properties and helps to prevent obesity risk, and/ or regulate body weight (Singh et al., 2012; Verma \& Patel, 2013; Gunashree et al., 2014), has low occurrence (1-2\%) in FM grain. Conversely, other millet grains contain higher amount of fat ranging from 3.5-5.2\% (Shahidi \& Chandrasekara, 2013). Low fat content together with dietary fibre and higher amounts of carbohydrates which are available in the form of non-starchy polysaccharides are essential in providing nutritional and physiological benefits such as hypocholestrolaemic and hypoglycemic effects (Vanithasri et al., 2012; Banusha \& Vasantharuba, 2013). Dietary fibre which

Table 4. Major vitamin content and fatty acids of finger millet.

\begin{tabular}{lcc}
\hline & $\mathrm{mg} / 100 \mathrm{~g}$ & References \\
\hline Vitamins & & Siwela (2009), Ramashia (2018). \\
Vit A (Retinol) & 6.0 & Saleh et al. (2013). \\
Vit B (Thiamine) & $0.2-0.48$ & Devi et al. (2014), Ramashia (2018). \\
Vit B (Riboflavin) & 0.12 & Saleh et al. (2013). \\
Niacin & $1.0-1.30$ & Siwela (2009), Shobana et al. (2013). \\
Vit C (Ascorbic acid) & $0.0-1.0$ & Fernandez et al. (2003). \\
Fatty acids & g/100 g of total lipids & Serna-Saldivar (2010). \\
Palmitic & $21.1-24.7$ & Serna-Saldivar (2010). \\
Oleic acid & 49.8 & Fernandez et al. (2003), Serna-Saldivar (2010), \\
Linoleic acid & 24.2 & Ramashia (2018). \\
Linolenic acid & $1.3-4.40$ & \\
\end{tabular}

Table 5. Essential and non-essential amino acids of finger millet.

\begin{tabular}{lcl}
\hline \multicolumn{1}{c}{ Amino acids } & g/ $\mathbf{1 0 0}$ g protein & \multicolumn{1}{c}{ References } \\
\hline Essential & & \\
Phenylalanine & $4.1-5.2$ & Siwela (2009), Serna-Saldivar (2010), Amadou et al. (2013). \\
Histidine & 2.2 & Serna-Saldivar (2010). \\
Isoleucine & 4.3 & Thapliyal \& Singh (2015), Ramashia (2018). \\
Leucine & $6.6-9.5$ & Serna-Saldivar (2010), Palanisamy et al. (2012). \\
Lysine & 2.2 & Thapliyal \& Singh (2015), Ramashia (2018). \\
Methionine & $2.5-3.1$ & Serna-Saldivar (2010), Palanisamy et al. (2012). \\
Threonine & $3.4-4.2$ & Serna-Saldivar (2010), Palanisamy et al. (2012). \\
Tryptophan & $1.1-1.5$ & Serna-Saldivar (2010), Palanisamy et al. (2012). \\
Valine & $4.9-6.6$ & Fernandez et al. (2003), Serna-Saldivar (2010). \\
Non-essential & & \\
Aspartic acid & $6.5-7.9$ & Fernandez et al. (2003), Serna-Saldivar (2010). \\
Glutamic acid & $20.3-27.1$ & Fernandez et al. (2003), Serna-Saldivar (2010). \\
Alanine & $6.1-6.2$ & Serna-Saldivar (2010), Amadou et al. (2013). \\
Arginine & $2.77-4.5$ & Fernandez et al. (2003), Serna-Saldivar (2010). \\
Cystine & $1.7-2.6$ & Siwela (2009), Serna-Saldivar (2010). \\
Glycine & $2.14-4.0$ & Fernandez et al. (2003), Serna-Saldivar (2010). \\
Proline & $7.0-9.9$ & Serna-Saldivar (2010), Amadou et al. (2013). \\
Serine & $3.6-5.1$ & Fernandez et al. (2003), Serna-Saldivar (2010). \\
Tyrosine & $2.79-3.6$ & Fernandez et al. (2003), Serna-Saldivar (2010). \\
\hline
\end{tabular}


contributes to high nutritional and functional importance is also present in FM grains. Dietary fibre which is classified into cellulose, pectin, arabinoxylan, lignin and $\beta$-glucan (Prashantha \& Muralikrishna, 2014), assist in determining the end-use quality of cereal-based food products.

Tryptin inhibitors, phytate, phytic acid, tannins and flavonoids which are present in FM grains are reported to contribute in reducing the bioavailability of minerals which brings about a reduction in the nutritional quality of FM (Palanisamy et al., 2012). However, phenolic acids and tannins are the main polyphenols present in FM, while flavonoids are reported to be available in small amounts. Polyphenols are regarded as major antioxidants that conduct activities which help to maintain the body immune system. Polyphenols occur naturally in a wide range of food products including FM grains (Siwela et al., 2007; Devi et al., 2014; Udeh et al., 2017). Tannins in the outer layer of the grain, serves as a physical barrier to fungal invasion (Devi et al., 2014) and plays an important role in the biological function of plants and humans. However, their anti-nutritional effects are partly negative because they reduce the digestibility of nutrients and the absorption of minerals. Recent studies have shown that some processing methods such as malting, fermentation, decortication, soaking, and steaming can improve the bio-availability of these nutrients (Sood et al., 2017; Sripriya et al., 1997; Platel et al., 2010; Krishnan et al., 2012; Dharmaraj and Malleshi, 2011). Tannins also inhibit growth because of their negative influence on the function of pancreases, the thyroid gland and can result in pathological alteration of the liver. Tannin compounds have been reported to affect colour, flavour, nutritional quality of the grains and products prepared from FM (Table 6). The compound also contributes to the antioxidant activity of FM foods which has been an important factor in healthy aging and the prevention of metabolic disease (Shibairo et al., 2014).

Health benefits of FM grains include slow release of glucose into the blood stream during digestion (Chappalwar et al., 2013; Mamatha \& Begum, 2013) as well as its effect in reducing constipation (Vanithasri et al., 2012). Finger millet grains are also reported to be associated with lowering the risk of diabetes, reduction of blood pressure and cardiovascular diseases (Pradeep \& Sreerama, 2015). Consumption of the grain has also been reported to reduce the risk of cancer (Subastri et al., 2015) and help to lower cholesterol levels (Table 6) (Asharani et al., 2010). Finger millet starch is used in the pharmaceutical industries as a binder for the preparation of granules and capsule dosage forms (Shiihii et al., 2011). Other benefits of FM are development and repair of body tissue, prevention of gallstones, protection against breast cancer and protection against postmenopausal women and childhood cancer (Verma \& Patel, 2013). The grains are also consumed as whole grains, are easily digestible and taste good (Thapliyal \& Singh, 2015). Finger millet grains are among the most important cereal grains for low socioeconomic communities especially Africa and some parts of Asian countries due to the grains serving as good sources of vitamins and fatty acids (Das et al., 2012; Verma \& Patel, 2013; Rurinda et al., 2014).

\section{Processing methods of finger millet grains}

Processing of FM grains through modern and traditional means, assist in converting the grains to edible forms of food products. Traditional forms of processing the grains include soaking, germination, malting, fermentation, milling or grinding, cooking, roasting and popping or puffing (Table 7) carried out mostly in rural areas (Hemalatha et al., 2007; Saleh et al., 2013; Dutta et al., 2015). The traditional processing of FM food products has received poor scientific applications especially in the developing countries. Thus, the use of modern processing technology in the manufacture of commercial products from FM is required (Saleh et al., 2013; Subastri et al., 2015).

Availability of value-added convenience food products from FM grains/ flours in urban areas promotes its consumption (Gunashree et al., 2014). Most research on FM has been conducted on the development of composite flours and extruded products which also increases the availability and awareness of FM food products in urban areas (Patel \& Verma, 2015). Presently, food scientists are more interested in neglected minor grains such as FM in order to reduce hunger and food shortage in developing countries. Accordingly, a huge percentage of people living in developing countries have limited access to animal food products, hence the need to consume highly nutritional FM food products that contributes significantly to their health (Tripathi \& Platel, 2010; Akhtar et al., 2011; Kunyanga et al., 2013).

Table 6. Potential health compounds of finger millet.

\begin{tabular}{|c|c|c|}
\hline Health compounds & Functions & References \\
\hline Ferulic acid & Prevents tissue damage and stimulates wound healing process. & Sarita \& Singh (2016). \\
\hline Phytic acid & Plays an important role in lowering body cholesterol. & $\begin{array}{l}\text { Amadou et al. (2013), Sarita \& Singh (2016), } \\
\text { Chandra et al. (2018). }\end{array}$ \\
\hline $\begin{array}{l}\text { Phytates, phenols and } \\
\text { Tannins }\end{array}$ & $\begin{array}{l}\text { Important in healing, aging and metabolic syndrome. Prevents } \\
\text { deterioration of human health, cancer and cardiovascular diseases. } \\
\text { Lowering of blood pressure and diabetes. Decreases tumour. }\end{array}$ & Siwela et al. (2007), Thilagavathi et al. (2015). \\
\hline Dietary fibre & $\begin{array}{l}\text { Essential for hypoglycemic and hypolipidemic effect as well as lowering } \\
\text { of serum cholesterol. Prevents atherosclerosis, antitoxic effect and anti- } \\
\text { cancerous effect. }\end{array}$ & Thilagavathi et al. (2015), Udeh et al. (2017). \\
\hline Nutraceutical foods & $\begin{array}{l}\text { Promotes better health by reducing the risk of chronic disease such as } \\
\text { obesity. Lowers blood pressure, cancer and diabetes. }\end{array}$ & Sarita \& Singh (2016). \\
\hline Magnesium & Reduces the risk of heart attack. & Chandra et al. (2018). \\
\hline Phosphorus & Essential for the development of body tissue and energy metabolism. & Chandra et al. (2018). \\
\hline
\end{tabular}


Table 7. Technological processes of finger millet food products.

\begin{tabular}{|c|c|c|c|}
\hline Processes & Functions & Examples of food products & References \\
\hline Soaking & Improves the bioavailability of minerals. & Soaked cereal grains. & Saleh et al. (2013). \\
\hline Malting & $\begin{array}{l}\text { Improves digestibility, nutritional value and } \\
\text { sensory attributes. }\end{array}$ & Weaning foods. & Verma \& Patel (2013). \\
\hline Fermentation & $\begin{array}{l}\text { Improves taste and nutritional properties. Helps } \\
\text { to preserve food products. Improves variety of } \\
\text { flavours as well as the nutritional properties of raw } \\
\text { materials. }\end{array}$ & $\begin{array}{l}\text { Ogi (thin porridge), beverage } \\
\text { and non-beverage drinks. }\end{array}$ & Verma \& Patel (2013), Saleh et al. (2013). \\
\hline Cooking & $\begin{array}{l}\text { Makes food palatable and safe for consumption. } \\
\text { Inactivates practically all the anti-nutritional } \\
\text { factors that are heat labile. }\end{array}$ & Porridge. & Kakade \& Hathan (2014). \\
\hline Puffing or popping & $\begin{array}{l}\text { Improves the nutritional value of foods. Enhances } \\
\text { appearance, colour, taste and aroma of the } \\
\text { processed raw materials. }\end{array}$ & $\begin{array}{l}\text { Snack, breakfast cereal and } \\
\text { ready-to-eat foods. }\end{array}$ & Verma \& Patel (2013), Saleh et al. (2013). \\
\hline Radiation & $\begin{array}{l}\text { Improves the nutritional quality of foods. Reduces } \\
\text { the antinutritional compounds in food. Used for } \\
\text { preservation of foods. }\end{array}$ & Canned foods. & Rodrigues et al. (2014). \\
\hline Extrusion & $\begin{array}{l}\text { Production of precooked and dehydrated foods. } \\
\text { Helps solve the problem of malnutrition. }\end{array}$ & $\begin{array}{l}\text { Noodles, macaroni, spaghetti, } \\
\text { baby foods and snacks. }\end{array}$ & Divate et al. (2015), Rathore et al. (2016). \\
\hline $\begin{array}{l}\text { Composite flour/ } \\
\text { Multi grains }\end{array}$ & $\begin{array}{l}\text { Improves food with low cost. Processing of local } \\
\text { food formulations. }\end{array}$ & $\begin{array}{l}\text { Finger millet/soya bean } \\
(70: 30) \text {. }\end{array}$ & Saleh et al. (2013), Chandra et al. (2018). \\
\hline
\end{tabular}

\subsection{Soaking}

Soaking is a process of adding distilled water to FM grains until the grains are fully steeped in water and left for an overnight period at an ambient temperature of 30 to $60^{\circ} \mathrm{C}$. The soaked water will then be discarded and the FM grains thoroughly cleaned and washed using clean water to remove foreign materials. The washed grains are then dried in a hot air oven at $60^{\circ} \mathrm{C}$ for $90 \mathrm{~min}$ before milling to flour (Banusha \& Vasantharuba, 2013). Soaking thus reduces the availability of antinutritional compounds such as phytic acid which increases the bioavailability of minerals like zinc (Saleh et al., 2013).

\subsection{Germination}

It is a traditional process where the whole unhusked grains are soaked for 2-24 $\mathrm{h}$ and then spread on a damp cloth for up to $24-48 \mathrm{~h}$ or incubated at $30^{\circ} \mathrm{C}$ for $48 \mathrm{~h}$ (Shimray et al., 2012). Germination process has been operated at low cost without the use of expensive equipment and it is an easily adaptable technology. Germination has been used for centuries to soften the kernel structure and improve the nutritional composition and concentration of carbohydrates, minerals, vitamins and essential amino acids, thus increasing the functional properties of the grains (Mbithi-Mwikya et al., 2000; Chove \& Mamiro, 2010; Pushparaj \& Urooj, 2011).

\subsection{Malting}

It is a combined process of steeping, germination, drying, toasting, grinding and sieving in order to achieve high nutritional quality, better starch digestibility, sensory properties and reduced antinutritional activities (Table 7). Malting improves the fibre, crude fat, vitamin B, C and mineral content in the grains, while antinutritional activities of tannins and phytic acid in brown millet are decreased significantly. Malting is a common technology used in Africa as malted FM grains are considered of best quality when compared to malted sorghum and maize (Banusha \& Vasantharuba, 2013; Sarkar et al., 2015; Thapliyal \& Singh, 2015). Dlamini \& Siwela, (2015) reported that malted FM millet is produced in small scale among rural dwellers to brew local beverages. The brewed grains are then used for refreshment during community ceremonies and for consumption by farmers engaged in farming activities (Rurinda et al., 2014).

\subsection{Milling or grinding}

It is the most common traditional processing method that converts dried and moistened cereal grains into flour by using wooden or stoned mortar and pestle. Milling or grinding is normally practiced in developing countries by mostly women (Young, 1999). The milling process of grains consists of sorting, cleaning, hulling, branning and kilning for further processing (Rasane et al., 2015). Finger millet grain requires dehulling and debranning before consumption because FM grain contains large portions of husk and bran. During milling process, about $10 \%$ of water is added to the grain in order to facilitate the removal of fibrous husk. Milling is mostly done to remove the fibrous coarse bran or the seed coat of the grains. Furthermore, removal of some phytochemicals such as phytates and tannin during milling improves the bioavailability of iron (Singh \& Raghuvanshi, 2012). 
Other methods of milling includes the use of modern and conventional equipment/ machines, conventional stone mills, burr mills (steel or emery type), hammer mills and ball mills. Upon completion of the milling process, the fine flour obtained is used for preparing chapatti while the coarse flour is normally used in the preparation of mudde, a compact ball made from FM dough (Table 7) and pez, a thin porridge or gruel (Patel \& Verma, 2015).

\subsection{Fermentation}

Fermentation is a processing method widely used on FM grains whereby the raw material becomes the medium of growth for the microorganism. The fermentation process as a means of food processing has been employed traditionally and continues to be applied in the production of fermented foods and beverages in homes, villages and in small-scale industries (Osungbaro, 2009). Finger millet may be fermented at room temperature for 24 to $72 \mathrm{~h}$ depending on the product or beverages intended to be produced. The most common indigenous FM based fermented food and beverages are produced in Africa (Ranasalva \& Visvanathan, 2014).

Presently, fermentation process has been upgraded and is now used in commercial industries to provide value-added products that meet the needs of the urban populace. It is also an economic process used for preserving food products (Blandino et al., 2003). During the fermentation process, growing microorganisms produce their own byproducts such as acids or antibiotics as they break down starch. This process in turn inhibits spoilage and pathogenic microorganisms, improves amino acid balance as well as the sensory quality and nutritional value of the grains (Ranasalva \& Visvanathan, 2014). Fermentation also provides health benefits by reducing antinutritional compounds such as tryptin, amylase inhibitor, phytic acid and tannins in cereal grains (Rasane et al., 2015). It should however be noted that each product of FM fermentation is associated with specific microorganisms (Table 8).

\subsection{Cooking}

It is a processing method that involves boiling FM grains in water until the grain becomes soft, mashed and again mixed with water to give a final product soup. Grueling helps to reduce the microbial load and improves the desirable sensory quality of the cooked grain (Khamgaonkar et al., 2013). Cooking of FM grains can also be prepared by mixing boiled water and flour to produce porridge (Emmambux \& Taylor, 2013).

\subsection{Puffing or popping}

Puffing or popping is a traditional method used for producing ready-to-eat and stable shelf-life products which are crunchy and porous (Singh \& Raghuvanshi, 2012; Dutta et al., 2015). Puffing also involves soaking whole unhusked grains in water and mixing with sand heated at $250^{\circ} \mathrm{C}$ for $15-60 \mathrm{~s}$. (Sarkar et al., 2015; Thapliyal \& Singh, 2015). Puffed snack foods are desirable in terms of colour, texture, flavour and shape thereby enhancing consumer acceptability.

Presently, modern air puffed machines have been developed for the mass production of puffing millet grains. Puffed FM can be milled to flour and further enriched with additional ingredients (Thapliyal \& Singh, 2015). Finger millet popped products have been reported to improve the pleasant aroma, acceptable taste and quality of grains by inactivating destructive bacteria (Thapliyal \& Singh, 2015). Puffing on its part, increases the digestibility and solubility of starch due to gelatinization (Table 7). Puffing also increases the dietary fibre of the final products and decreases antinutritional factors (Choudhury et al., 2011; Sarkar et al., 2015).

\subsection{Roasting}

It is a simple traditional technology commonly practiced in households and rural areas. Roasting is similar to puffing process but differs in the volume expansion which is higher in puffing. During roasting, the antinutritional or toxic effect such as saponins, alkaloids, glycosides, gioterogenic agents, tryptin inhibitor and hemagglutinin are removed. Roasting improves the nutritional quality and increases the shelf-life of the roasted grains (Table 7). Processed foods obtained as a result of roasting of FM grains include weaning foods which increases the bioavailability of iron (Singh \& Raghuvanshi, 2012; Thapliyal \& Singh, 2015).

Table 8. Common indigenous millet-based fermented foods and beverages.

\begin{tabular}{lcc}
\hline \multicolumn{1}{c}{ Products } & Microorganisms & Countries \\
\hline Busa (liquid drink) & Lactobacillus, Sacchromyces & Egypt \\
Chikokivana (alcoholic beverage) & Sacchromyces cerevisiae & Zimbabwe \\
Dalaki (thick porridge) & Unknown & Nigeria \\
Doro (colloidal, thick, alcoholic drink) & Yeast and bacteria & Zimbabwe \\
Bogobe (solid dough) & Lactobacillus sp., yeast & Botswana and Ghana \\
Kenkey (solid dough) & Lactobacillus sp., yeast & Botswana and Ghana \\
Kwanu-Zaki (liquid drink) & LAB, Yeast & Nigeria \\
Ogi (liquid porridge) & Lactobacillus sp., Aerobacter & Nigeria \\
Merissa (alcoholic drink) & Sacchromyces & Sudan \\
Mahewu (liquid porridge) & Unknown & East African Countries \\
Munkoyo (liquid drink) & Lactobacillus delbrukii, L. bulgarius, Streptococcus lactis & Africa \\
Uji (porridge as staple foods) & Leuconostoc mesenterodes & Uganda, Tanganyika \\
\hline
\end{tabular}

\footnotetext{
Source: Osungbaro (2009), Blandino et al. (2003).
} 


\subsection{Extrusion}

It is a modern food processing method applied to foods and used in solving problems associated with the processing of small cereal based products in terms of physical state, quality, functionality and shelf-life extension (Table 7). Extrusion process has many advantages in terms of preparation of ready-to-eat foods desired in different shapes, size, texture and sensory characteristics (Vanithasri et al., 2012; Dhurve et al., 2015). Extrusion has also found application in solving the problem of malnutrition in developing countries due to its beneficial process. The cooking process employed is high temperature for a short time which is used in processing starchy materials. Common advantages of extrusion cooking include low cost, high productivity, speed and high product quality. Extrusion also assists in product development without waste, increases in-vitro protein digestibility, versatility, unique product shapes and energy savings (Manjula \& Visvanathan, 2014; Divate et al., 2015; Gat \& Ananthanarayan, 2015). During the extrusion process, protein solubility and structure are decreased and disrupted when applied under high pressure and temperature (Manjula $\&$ Visvanathan, 2014). Extrusion is a process of gelatinizing and cooking the product completely until it is fully cooked, thereby leading to the production of different forms of food.

The extrusion process is extensively applied in food industries to make breakfast cereals and snacks. Flour from various plant sources can be prepared in different forms to produce common extruded products such as snacks, noodles, macaroni, spaghetti, baby foods and pasta which are preferred by children and teenagers. Furthermore, this technology can be applied in the preparation of pet foods which are very convenient and requires short time to prepare. Snacks are ready-to-eat products which are very popular and whose demand is increasing among all age groups (Limsangouan et al., 2010; Siddhart, 2014; Thapliyal \& Singh, 2015; Masli et al., 2018). Fortification of extruded products with minerals and vitamins is also employed to balance the nutritional composition that is lost during processing and to prevent micronutrient deficiencies (Towo et al., 2006; Ottaway, 2008). The extruded products can be coated with sweet or savory flavors to appeal to children (Mariotti et al., 2006; Thapliyal \& Singh, 2015).

\subsection{Radiation process}

Food irradiation technology is a process in which packed foods are subjected to controlled ionizing radiation in the form of x-rays, alpha, beta and gamma rays (Manjula et al., 2015). The technology is also in the preservation of foods by extending their shelf-life. This contributes to better quality products, improves the nutritional quality of foods and reduces antinutritional compounds (Singer et al., 2006; Pushparaj \& Urooj, 2011; Rodrigues et al., 2014). Food irradiation has been recommended by other researchers as an efficient, potential food preservation process used in food processing industries. The United States, France, Canada and United Kingdom are among 42 countries which have been given clearance to use radiation in their food processing industries (Manjula et al., 2015).
Traditional processing technologies such as germination, soaking, fermentation, puffing and cooking reduces the level of tannins and phenols while increasing the bioavailability of micronutrients (Devi et al., 2014; Gunashree et al., 2014; Sarkar et al., 2015). However, new processing and preparation methods are needed to enhance the bioavailability of micronutrients and improve the quality of millet diets in humans (Pradeep \& Sreerama, 2015). The commercialisation of FM food products that may be consumed by people, especially those suffering from celiac disease and diabetes is important more so as the demand for gluten-free food product is increasing in urban areas (Angioloni \& Collar, 2012).

\section{Compositing finger millet flour and bakery products}

Composite flour is a technological process of mixing wheat flour and flour from other cereal grains such as finger millet (Devani et al., 2016). Compositing is usually applied in the preparation of bakery products including biscuits, muffins, rusk, cakes and bread which possess good texture, appearance, flavour and sensory acceptability. The processing technique has also been used by mixing non-wheat flours, roots and tubers and other raw edible materials. Compositing has equally found application in the fortification of one material with another for enhanced nutritional quality and sensory attributes (Rajiv et al., 2011; Thapliyal and Singh 2015). Studies have been conducted where FM flour was combined with wheat flour to produce baked products and pastries (Singh et al., 2012; Sawant et al., 2013; Noorfarahzilah et al., 2014). The specified ratios of compositing leads to an increase in the concentration of proteins, fat, phosphorus, dietary fibre, calcium, ash content, tannin and phytic acid in the final processed food product (Chhavi \& Savita, 2012; Thapliyal \& Singh, 2015). Furthermore, Shahidi \& Chandrasekara (2013) and Patel et al. (2014) reported that most research on multigrain products have been focused mostly on gluten-free products and are regarded as the present day niche focus areas or markets.

\section{Use and application of finger millet grains/flours}

Finger millet grains are used primarily in the production of traditional foods such as alcoholic and non-alcoholic beverages (Table 8), while its flour is utilised in the manufacture of different types of FM value-added food products (Figure 2). The grains are also used in the preparation of geriatric, infant and health foods both in the natural and malted form (Kulkarni et al., 2012). Most food products of FM grain or flour origin are not commercialized, especially those produced in the developing countries. Conversely, food products obtained from sorghum and wheat are commercialised and sold in supermarkets or retail shops around the world (Roopa \& Premavalli, 2008; Siwela, 2009). Towo et al. (2006) reported that foods prepared from grain/flour of FM differ from country to country and occasionally from region to region. Abulude et al. (2005) also reported that FM grains are not toxic to health at any stage of consumption yet, FM grains are neglected despite their nutritional advantages.

Some recent studies on FM grain highlighting opportunities for research, utilisation and health benefits in developing countries 
are presented in Table 9. The foregoing discussion shows that more research needs to be conducted on FM grains, especially in the developed countries, with research on FM focusing on the increased consumption of the grain products in developed countries (Jideani, 2012; Amadou et al., 2013). This may help in reducing the occurrence of ischemic strokes, cardiovascular diseases, cancers, obesity and type II diabetes especially among elderly people living in these countries (Kaur et al., 2014).
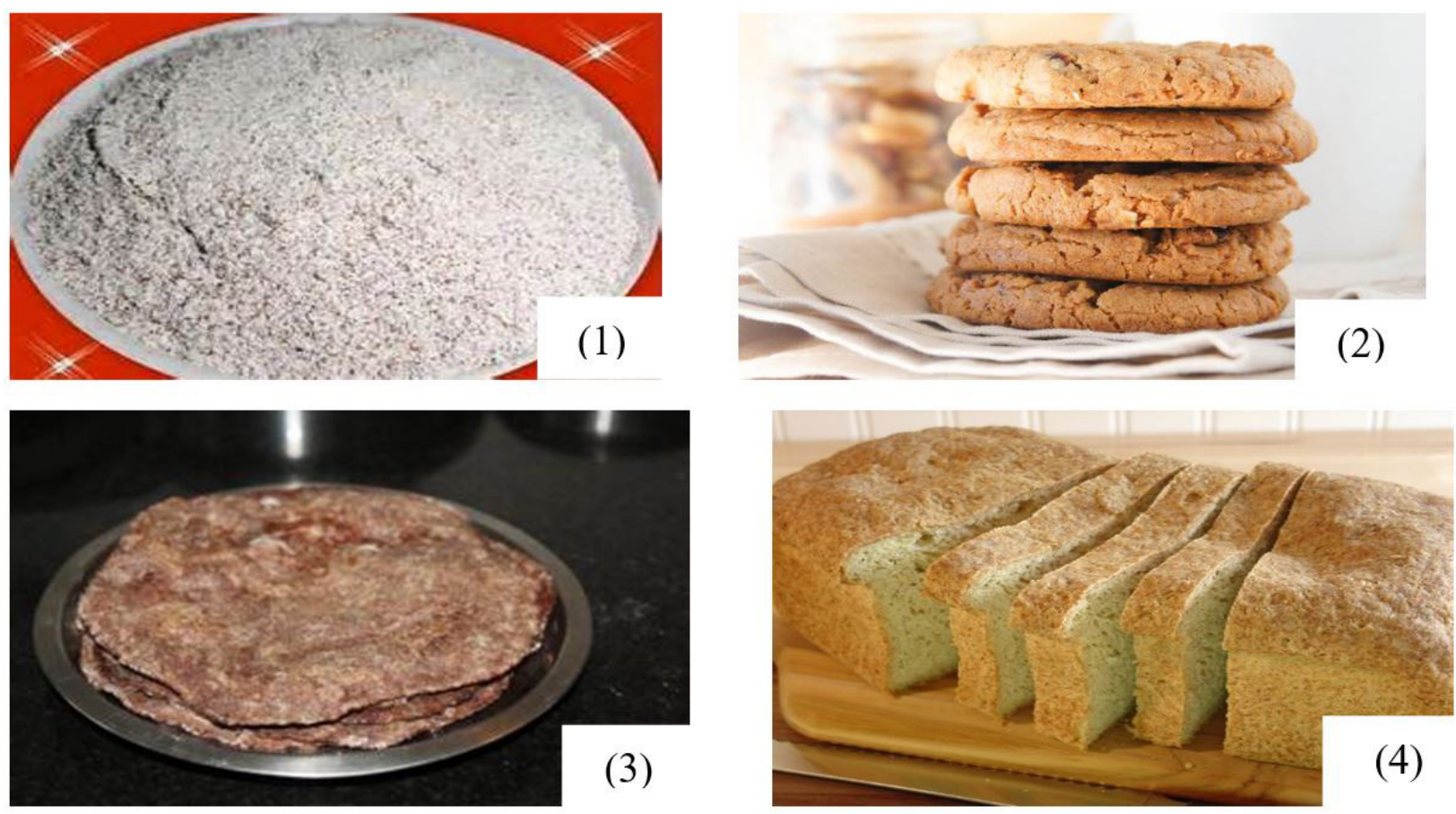

Figure 2. Finger millet value-added products: $(1)=$ finger millet flour; $(2)=$ Ragi cookies, $(3)=$ Finger millet roti and $(4)=$ Ragi puttu. Source: Ramashia (2018).

Table 9. Identified research gaps on scientific investigation of finger millet grains/flours.

Previous studies
Gaps in knowledge, needs and opportunities for new
research and development of proposal for the formation of
network of scientific and research programmes in the world
on FM.

Utilization, health benefits and value-added products made from FM (tamba)

Focused on the nutritional characteristics, health benefits and developing value-added products from millets.

Processing, nutritional quality, improvement of FM grains and their food products.

Discussed the few value-added food products incorporating ragi and simultaneous attempts to enlist and document the methodology and techniques in the interest of scientist and common masses.

The FM was incorporated with noodles for the management of diabetes disorders.

Improvement of agricultural production and food security as well as conservation of environmental resources and assistance to farmers to cope with increasing climatic stresses in future.

\section{Research gap}

Technology needs to be applied to commercial development as African urbanization is increasing the demand for processed, value-added, convenience food products that meets the need of the urban consumer. Development and commercial industries that can produce traditional African FM foods.

Commercialisation, encouragement and increase in the consumption of fortified FM in urban areas is needed.

Future trends should focus on millet consumption in developed countries that could help its industrial revolution. Availability, use of millet grains in urban areas and opening of new markets for farmers in order to improve their income. Development of highly improved products from millet is also needed. New processing and preparation methods are needed to enhance the bioavailability of the micronutrients and improve the quality of millet diets in human.

Modern trends for the development of new food products. Aspires for complementary foods in order to fulfill the widening gap of food availability and nutritional security.

Commercialisation of FM food products that may serve the people suffering from diabetes is important.

Educate the community and farmers on the importance of indigenous food products, especially the nutritional composition.
References

Belton \& Taylor (2004)

Jeani (2012).

Amadou et al. (2013).

Saleh et al. (2013).

Verma \& Patel (2013).

Shukla \& Srivastava (2014).

Abraham et al. (2014). 


\section{Conclusion}

The grain FM can be seen to contribute to food security, especially for low income populations across the globe. Focus of previous research on traditional FM products and not on commercialized processed FM products, has made information on innovative research of FM to be scarce. This is more so when comparing studies on FM with that of other major cereals such as maize, wheat and rice. Moreover, the nutritional and health benefits of FM confer on this gluten-free cereal a huge potential for commercial exploitation. Though a lot of improvement still needs to be done in the commercialisation of African FM foods, ways of increasing utilization of the grains through traditional and commercial methods are also needed. There is thus a necessity for further research on FM by food scientists, government agencies, non-governmental organizations, research institutions and industries to generate more information on FM utilization. Commercialisation and development of value-added fortified FM and other gluten-free products holds a lot of potential as the availability of commercialised FM products in developed countries will assist in mitigating the incident of celiac disease and obesity.

\section{References}

Abraham, B., Araya, H., Berhe, T., Edwards, S., Gujja, B., Khadka, R. B., Koma, D. S., Sharif, A., Styger, E., Uphoff, N., \& Verma, A. (2014). The system of crop intensification: reports from the field on improving agricultural production, food security, and resilience to climate change for multiple crops. Agriculture \& Food Security, 3(4), 1-12. Retrieved from http://www.agricultureandfoodsecurity. com/content $/ 3 / 1 / 4$

Abulude, F. O., Lawal, L. O., \& Kayode, A. O. (2005). Effect of processing on some functional properties of millet (Eleusine coracana) flour. Journal of Food Technology, 3(3), 460-463. Retrieved from http:// docsdrive.com/pdfs/medwelljournals/jftech/2005/460-463.pdf

Adhikari, R. K. (2012). Economic of finger millet (Eleusine coracana G.) Production and marketing in Peri urban area of Pokhara valley of Nepal. Journal of Development and Agricultural Economics, 4(60), 151-157. http://dx.doi.org/10.5897/JDAE11.119.

Akhtar, S., Anjum, F. M., \& Anjum, M. A. (2011). Micronutrient fortification of wheat flour: recent development and strategies. Food Research International, 44(3), 752-659. http://dx.doi.org/10.1016/j. foodres.2010.12.033.

Amadou, I., Mahamadou, E. G., \& Le, G.-W. (2013). Millets, nutritional composition, some health benefits and processing - Review. Food Science and Technology (Campinas), 25(7), 501-508. http://dx.doi. org/10.9755/ejfa.v25i7.12045.

Angioloni, A., \& Collar, C. (2012). Effects of pressure treatment of hydrated oat, finger millet and sorghum flours on the quality and nutritional properties of composite wheat breads. Journal of Cereal Science, 56(3), 713-719. http://dx.doi.org/10.1016/j.jcs.2012.08.001.

Asharani, V. T., Jayadeep, A., \& Malleshi, N. G. (2010). Natural antioxidants in edible flours of selected small millets. International Journal of Food Properties, 13(1), 41-50. http://dx.doi.org/10.1080/10942910802163105.

Banusha, S., \& Vasantharuba, S. (2013). Effect of malting on nutritional contents of finger millet and mung bean. American-Eurasian Journal of Agriculture and Environmental Science, 13(12), 1642-1646. http:// dx.doi.org/10.5829/idosi.aejaes.2013.13.12.12285.
Belton, P. S., \& Taylor, J. R. N. (2004). Sorghum and millets: protein sources for Africa. Trends in Food Science \& Technology, 15(2), 9498. http://dx.doi.org/10.1016/j.tifs.2003.09.002.

Blandino, A., Al-Aseeri, M. E., Pandiella, S. S., Cantero, D., \& Webb, C. (2003). Cereal-based fermented foods and beverages. Food Research International, 36(6), 527-543. http://dx.doi.org/10.1016/ S0963-9969(03)00009-7.

Blench, R. (2012). Finger millet: the contribution of vernacular names towards its prehistory. Archaeological and Anthropological Sciences, 8(1), 79-88. http://dx.doi.org/10.1007/s12520-012-0103-6.

Chandra, A., Singh, A. K., \& Mahto, B. (2018). Processing and value addition of finger millet to achieve nutritional and financial security - case study. International Journal of Current Microbiology and Applied Sciences, 7, 2901-2910. Retrieved from https://www.ijcmas. com/special/7/Anjali\%20Chandra,\%20et\%20al.pdf

Chappalwar, V. M., Peter, D., Bobde, H., \& John, S. M. (2013). Quality characteristics of cookies prepared from oats and finger millet based composite flour. Engineering Science and Technology: An International Journal (Toronto, Ont.), 3(4), 667-683. Retrieved from http://www. estij.org/papers/vol3no42013/11vol3no4.pdf

Chhavi, A., \& Savita, S. (2012). Evaluation of composite millet breads for sensory and nutritional qualities and glycemic response. Malnutrition Journal of Nutrition, 18(1), 89-101. Retrieved from https://www. ncbi.nlm.nih.gov/pubmed/23713233

Choudhury, M., Das, P., \& Baroova, B. (2011). Nutritional evaluation of popped and malted indigenous millet of Assam. Food Science and Technology (Campinas), 48(6), 706-711. PMid:23572808. http:// dx.doi.org/10.1007/s13197-010-0157-3.

Chove, E. B., \& Mamiro, P. S. (2010). Effect of germination and autoclaving of sprouted finger millet and kidney beans on cyanide content. Tanzania Journal of Health, 12(4), 261-267. http://dx.doi. org/10.1007/s13197-010-0157-3. PMid:24409633.

Das, A., Raychaudhuri, Y., \& Chakraborty, R. (2012). Cereal based functional food of Indian subcontinent - a review. Journal of Food Science and Technology, 49(6), 665-672. http://dx.doi.org/10.1007/ s13197-011-0474-1. PMid:24293685.

Devani, B. M., Jani, B. L., Kapopara, M. B., Vyas, D. M., \& Ningthoujam, M. D. (2016). Study on quality of white bread enriched with finger millet flour. International Journal of Agriculture Environment and Biotechnology, 9(5), 903-907. http://dx.doi.org/10.5958/2230732X.2016.00116.9.

Devi, P. B., Vijayabharathi, R., Sathyabama, S., Malleshi, N. G., \& Priyadarisini, V. B. (2014). Health benefits of finger millet (Eleusine coracana $\mathrm{L}$ ) polyphenols and dietary fibre - Review. Journal of Food Science and Technology, 6(6), 1021-1040. http://dx.doi.org/10.1007/ s13197-011-0584-9. PMid:24876635.

Dharmaraj, U., \& Malleshi, N. G. (2011). Changes in carbohydrates, proteins and lipids of finger millet after hydrothermal processing. Lebensmittel-Wissenschaft + Technologie, 44(7), 1636-1642. http:// dx.doi.org/10.1016/j.lwt.2010.08.014.

Dhurve, P., Bakane, P. H., \& Agrawal, S. (2015). Optimisation of process parameters of finger millet-soy pasta using response surface methodology. International Journal of Engineering Research and General Science, 3(2), 415-427. Retrieved from http://pnrsolution. org/Datacenter/Vol3/Issue2/60.pdf

Dionex Corporation. (2010). Determination of water-and fat-soluble vitamins by HPLC (Technical Note, No. 89, LPN 2598). Sunnyvale: Dionex Corporation. Retrieved from https://tools.thermofisher.com/ content/sfs/brochures/88784-TN89-HPLC-WaterFatSolubleVitamins27 Oct 
Divate, A., Sawant, A. A., \& Thakor, N. J. (2015). Effect of extruder temperature on functional characteristics of finger millet [Eleusine coracana (L) Gaertn] based extrudates. Global Science Research Journals, 3(6), 239-246. Retrieved from http://www.globalscienceresearchjournals. org/gjas/877382015392.pdf

Dlamini, N. R., \& Siwela, M. (2015). The future of grain science: the contribution of indigenous small grains to food security, nutrition, and health in South Africa. Cereal Foods World, 60(4), 177-180. http://dx.doi.org/10.1094/CFW-60-4-0177.

Dutta, A., Mukherjee, R., Gupta, A., Ledda, A., \& Chakraborty, R. (2015). Ultrastructural and physicochemical characteristics of rice under various conditions of puffing. Journal of Food Science and Technology, 52(11), 7037-7047. http://dx.doi.org/10.1007/s13197-015-1808-1.

Emmambux, M. N., \& Taylor, J. R. N. (2013). Morphology, physical, chemical, and functional properties of starches from cereals, legumes, and tubers cultivated in Africa - review. Starch, 65(9-10), 715-729. http://dx.doi.org/10.1002/star.201200263.

Fernandez, D. R., Vanderjagt, D. J., Millson, M., Huang, Y., Chuang, L., Pastuszyn, A., \& Glew, R. H. (2003). Fatty acid, amino acid and trace mineral composition of Eleusine coracana (pwana) grains from Northern Nigeria. Plant Foods for Human Nutrition (Dordrecht, Netherlands), 58(3), 1-10. http://dx.doi.org/10.1023/B:QUAL.0000040323.67339. cb. PMid:12859008.

Food and Agricultural Organisation - FAO. (2016). Retrieved from http//faostat.fao.org

Gat, Y., \& Ananthanarayan, L. (2015). Effect of extrusion process parameters and pregelatinized rice flour on physico-chemical properties of ready-to-eat expanded snacks. Journal of Food Science and Technology, 52(5), 2634-2645. http://dx.doi.org/10.1007/s13197014-1378-7. PMid:25892761.

Gull, A., Jan, R., Nayik, G. A., Prasad, K., \& Kumar, P. (2014). Significance of finger millet in nutrition, health and value added products: a review. Journal of Environmental Science, Computer Science and Engineering and Technology, 3(3), 1601-1608. Retrieved from www.jecet.org

Gunashree, B. S., Kumar, R. S., Roobini, R., \& Venkateswaran, G. (2014). Nutrients and antinutrients of ragi and wheat as influenced by traditional processes. International Journal of Current Microbiology and Applied Sciences, 3(7), 720-736. Retrieved from http://ir.cftri. com/12404

Hemalatha, S., Platel, K., \& Srinivasan, K. (2007). Influence of germination and fermentation on bioaccessibility of zinc and iron from food grains. European Journal of Clinical Nutrition, 61(3), 342-348. http:// dx.doi.org/10.1038/sj.ejcn.1602524. PMid:16969377.

Jayasinghe, M. A., Ekanayake, S., \& Nugegoda, D. B. (2013). Effect of different milling methods on glycemic response of foods made with finger millet (Eleusine coracana) flour. The Ceylon Medical Journal, 58(4), 148-152. http://dx.doi.org/10.4038/cmj.v58i4.6305. PMid:24385055.

Jideani, I. A. (2012). Digitaria exilis (acha/ fonio), Digitaria iburua (iburu/ fonio) and Eleusine coracana (tamba/ finger millet) - Nonconventional cereal grains with potentials. Scientific Research and Essays, 7(45), 3834-3843. http://dx.doi.org/10.5897/SRE12.416.

Jideani, I. A., \& Jideani, V. A. (2011). Developments on the cereal grains Digitaria exilis (acha) and Digitaria iburua (iburu). Journal of Food Science and Technology, 48(3), 251-259. http://dx.doi.org/10.1007/ s13197-010-0208-9. PMid:23572743.

Jideani, I. A., Takeda, Y., \& Hizukuri, S. (1996). Structures and physiochemical properties of acha (Digitaria exilis), iburu (D. iburua) and tamba (Eleusine coracana). Cereal Chemistry, 73(6), 677-685. Retrieved from http://www.aaccnet.org/publications/cc/backissues/1996/ documents/73_677.pdf
Kakade, S. B., \& Hathan, B. S. (2014). Finger millet processing - review. International Journal of Agriculture Innovations and Research, 3(4), 1003-1008. Retrieved from http://www.ijair.org/administrator/ components/com_jresearch/files/publications/IJAIR-1074_final.pdf

Kaur, K. D., Jha, A., Sabikhi, L., \& Singh, A. K. (2014). Significance of coarse cereals in health and nutrition: A review. Journal of Food Science and Technology, 51(8), 1429-1441. http://dx.doi.org/10.1007/ s13197-011-0612-9. PMid:25114333.

Khamgaonkar, S. G., Singh, A., Chand, K., Shahi, N. C., \& Lohani, U. C. (2013). Processing technologies of Uttarakhand of lesser known crops: an overview. Journal of Academic Industry Research, 1(8), 447452. Retrieved from http://jairjp.com/JANUARY\%202013/04\%20 KHAMGAONKAR.pdf

Krishnan, R., Dharmaraj, U., \& Malleshi, N. G. (2012). Influence of decortication, popping and malting on bioavailability of calcium, iron and zinc in finger millet. Lebensmittel-Wissenschaft + Technologie, 48(2), 169-174. http://dx.doi.org/10.1016/j.lwt.2012.03.003.

Kulkarni, S. S., Desai, A. D., Ranveer, R. C., \& Sahoo, A. K. (2012). Development of nutrient rich noodles by supplementation with malted ragi flour. International Food Research Journal, 19(1), 309313. Retrieved from http://www.ifrj.upm.edu.my/19\%20(01)\%20 2011/(41)IFRJ-2011-136\%20Sahoo.pdf

Kumar, A., Metwal, M., Kaur, S., Gupta, A. K., Puranik, S. S., Singh, M., Singh, M., Gupta, S., Babu, B. K., Sood, S., \& Yadav, R. (2016). Nutraceutical value of finger millet [Eleusine coracana (L.) Gaertn.], and their improvement using omics approaches. Frontiers in Plant Science, 7, 1-14. http://dx.doi.org/10.3389/fpls.2016.00934.

Kunyanga, C. N., Imungi, J. K., \& Vellingiri, V. (2013). Nutritional evaluation of indigenous foods with potential food-based solution to alleviate hunger and malnutrition in Kenya. Journal of Applied Biosciences, 67(0), 5277-5288. http://dx.doi.org/10.4314/jab.v67i0.95049.

Limsangouan, N., Takenaka, M., Sotome, I., Nanamyama, K., Charunuch, C., \& Isobe, S. (2010). Functional properties of cereal and legume based extruded snack foods fortified with by-products from herbs and vegetables. Journal of Natural Science, 44, 271-279. Retrieved from http://kasetsartjournal.ku.ac.th/kuj_files/2010/ A1004071451290937.pdf

Mamatha, H. S., \& Begum, J. M. (2013). Nutrition analysis and cooking quality of finger millet (Eleusine coracana) vermicelli with hypoglycemic foods. International Journal of Farm Sciences, 3(2), 56-62. Retrieved from https://www.inflibnet.ac.in/ojs/index.php/ IJFS/article/download/2318/1883

Manjula, B., \& Visvanathan, R. (2014). Process optimisation of extruded breakfast cereal from rice mill brokens-finger millet-maize flour blends. International Journal of Food and Nutritional Sciences, 3(4), 66-71. Retrieved from www.ifans.com/currentissue.html

Manjula, K., Bhagath, Y. B., \& Nagalakshmi, K. (2015). Effect of radiation processing on bioactive components of finger millet flour (Eleusine coracana L.). International Food Research Journal, 22(2), 556-560. Retrieved from http://www.ifrj.upm.edu.my/22\%20(02)\%202015/ (16).pdf

Mariotti, M., Alamprese, C., Pagani, M. A., \& Lucisano, M. (2006). Effect of puffing on ultrastructure and physical characteristics of cereal grains and flours. Journal of Cereal Science, 43(1), 47-56. http://dx.doi.org/10.1016/j.jcs.2005.06.007.

Masli, M. D. P., Gu, B.-J., Rasco, B. A., \& Ganjyal, G. M. (2018). Fiber-rich food processing byproducts enhance the expansion of cornstarch extrudates. Journal of Food Science, 83(10), 2500-2510. http://dx.doi. org/10.1111/1750-3841.14290.

Mathanghi, S. K., \& Sudha, K. (2012). Functional and Phytochemical properties of finger millet (Eleusine coracana) for health. International 
Journal of Pharmaceutical, Chemical and Biological Sciences, 2(4), 431438. Retrieved from http://www.ijpcbs.com/files/volume2-4-2012/4.pdf

Mathur, P. N. (2012). Global strategy for the ex situ conservation of finger millet and its wild relatives (pp. 1-62). New Delhi, India: Biodiversity International, Sub-regional Office for South Asia, NASC Complex, Pusa Campus. Retrieved from https://www.croptrust.org/wp-content/ uploads/2014/12/Finger-Millet-Strategy-FINAL-14May2012.pdf.

Mbithi-Mwikya, S., van Camp, J., Yiru, Y., \& Huyghebaert, A. (2000). Nutrient and antinutrients changes in finger millet (Eleusine coracana) during sprouting. Lebensmittel-Wissenschaft + Technologie, 33(1), 9-14. http://dx.doi.org/10.1006/fstl.1999.0605.

Muthamilarasan, M., Dhaka, A., Yadav, R., \& Prasad, M. (2016). Exploration of millet models for developing nutrients rich graminaceous crops. Plant Science, 242, 89-97. http://dx.doi. org/10.1016/j.plantsci.2015.08.023. PMid:26566827.

Noorfarahzilah, M., Lee, J. S., Sharifodin, M. S., \& Hasmadi, M. (2014). Application of composite flour in development of food products. International Food Research Journal, 21(6), 2061-2074. Retrieved from http://www.ifrj.upm.edu.my/21\%20(06)\%202014/1\%20IFRJ\%20 21\%20(06)\%202014\%20Hasmadi\%20124.pdf

Osungbaro, T. O. (2009). Physical and nutritive properties of fermented cereal foods. African Journal of Food Science, 3(2), 23-27. Retrieved from http://www.academicjournals.org/article/article1380633566_ Taiwo.pdf

Ottaway, P. B. (2008). Food fortification and supplementation. Technological, safety and regulatory aspects. England: CRC Press. . http://dx.doi. org/10.1533/9781845694265.

Palanisamy, B. D., Rajendran, V., Sathyaseelan, S., Bhat, R., \& Venkatesan, B. P. (2012). Enhancement of nutritional value of finger millet-based food (Indian dosa) by co-fermentation with horse gram flour. International Journal of Food Sciences and Nutrition, 63(1), 5-15. http://dx.doi.org/10.3109/09637486.2011.591367. PMid:21696301.

Pandhre, G. R., Satwase, A. N., \& Hashmi, A. I. (2011). Studies on drying characteristics and nutritional composition of sprouted wheat and finger millet. International Journal of Current Research, 3(7), 218-221. Retrieved from http://www.journalcra.com/sites/ default/files/Download\%20864.pdf

Patel, S., \& Verma, V. (2015). Ways for better utilization of FM through processing and value addition and enhance nutritional security among tribals. Global Journal of Medical Research Nutrition and Food Science, 15(1), 22-29.

Patel, S., Naik, R. K., Sahu, R., \& Nag, S. K. (2014). Entrepreneurship development through finger millet processing for better livelihood in production catchment. American International Journal of Research in Humanities, Arts and Social Sciences, 8(2), 223-227. Retrieved from http://iasir.net/AIJRHASSpapers/AIJRHASS14-711.pdf

Platel, K., Eipeson, S. W., \& Srinivasan, K. (2010). Bioaccessible mineral content of malted finger millet (Eleusine coracana), wheat (Triticum aestivum), and barley (Hordeum vulgare). Journal of Agricultural and Food Chemistry, 58(13), 8100-8103. http://dx.doi.org/10.1021/ jf100846e. PMid:20560601.

Pradeep, P. M., \& Sreerama, Y. N. (2015). Impact of processing on the phenolic profiles of small millets: Evaluation of their antioxidant and enzyme inhibitory properties associated with hyperglycemia. Food Chemistry, 9, 455-463. http://dx.doi.org/10.1016/j.foodchem.2014.08.010. PMid:25236251.

Prashantha, M. R. S., \& Muralikrishna, G. (2014). Arabinoxylan from finger millet (Eleusine coracana, v. Indaf 15) bran purification and characterization. Carbohydrates Polymers, 99, 800-807.
Pushparaj, F. S., \& Urooj, A. (2011). Influence of processing of dietary fibre, tannin and in Vitro protein digestibility of pearl millet. Food and Nutrition Sciences, 2(08), 895-900. http://dx.doi.org/10.4236/ fns.2011.28122.

Rajiv, J., Soumya, C., Indrani, D., \& Venkateswara Rao, G. (2011). Effect of replacement of wheat flour with finger millet flour (Eleusine coracana) on the batter microscopy, rheology and quality characteristics of muffins. Journal of Texture Studies, 42(6), 478-489. http://dx.doi. org/10.1111/j.1745-4603.2011.00309.x.

Ramashia, S. E. (2018). Physical, functional and nutritional properties offlours from finger millet (Eleusine coracana) varieties fortified with vitamin $B 2$ and zinc oxide ( $\mathrm{PhD}$ thesis). Retrieved from http://hdl. handle.net/11602/1245

Ramashia, S. E., Gwata, E. T., Meddows-Taylor, S., Anyasi, T. A., \& Jideani, A. I. O. (2018). Some physical and functional properties of finger millet (Eleusine coracana) obtained in sub-Saharan Africa. Food Research International, 104, 113-118. http://dx.doi.org/10.1016/j. foodres.2017.09.065. PMid:29433775.

Ranasalva, N., \& Visvanathan, R. (2014). Development of bread from fermented pearl millet flour. Food Processing \& Technology, 5(5), 2-5. http://dx.doi.org/10.4172/2157-7110.1000327.

Rasane, P., Jha, A., Sabikhi, L., Kumar, A., \& Unnikrishnan, V. S. (2015). Nutritional advantages of oats and opportunities for processing as value-added foods - Review. Journal of Food Science and Technology, 52(2), 662-675. http://dx.doi.org/10.1007/s13197-013-1072-1. PMid:25694675.

Rathore, S., Singh, K., \& Kumar, V. (2016). Millet grain processing, utilization and its role in health promotion - a review. International Journal of Nutrition and Food Sciences, 5(5), 318-329. http://dx.doi. org/10.11648/j.ijnfs.20160505.12.

Rodrigues, M., Mandalika, S., Jamdar, S. N., \& Sharma, A. (2014). Evaluation of the efficacy of malted, gamma irradiated and enzymatically processed finger millet-soybean blends in supporting growth of a mixed culture of lactic acid bacteria. Food Science and Technology (Campinas), 59, 908-914. http://dx.doi.org/10.1016/j. lwt.2014.07.006.

Roopa, S., \& Premavalli, K. S. (2008). Effect of processing on starch fractions in different varieties of finger millet. Food Chemistry, 106(3), 875-882. http://dx.doi.org/10.1016/j.foodchem.2006.08.035.

Rurinda, J., Mapfumo, P., van Wijk, M. T., Mtambanengwe, F., Rufino, M. C., Chikowo, R., \& Giller, K. E. (2014). Comparative assessment of maize, finger millet and sorghum for household food security in the face of increasing climatic risk. European Journal of Agronomy, 55, 29-41. http://dx.doi.org/10.1016/j.eja.2013.12.009.

Saleh, S. M., Zhang, Q., Chen, J., \& Shen, Q. (2013). Millet grains, nutritional quality, processing and potential health benefits. Comprehensive Reviews in Food Science and Technology, 12(3), 281295. http://dx.doi.org/10.1111/1541-4337.12012.

Sarita, E. S., \& Singh, E. (2016). Potential of millets: nutrients composition and health benefits. Journal of Scientific \& Innovative Research, 5(2), 46-50. Retrieved from https://www.jsir.journal.com

Sarkar, P., Lohith Kumar, D. H., Dhumal, C., Panigrahi, S. S., \& Choudhary, R. (2015). Traditional and ayurvedic foods of Indian origin. Journal of Ethnic Foods, 2(3), 97-109. http://dx.doi.org/10.1016/j.jef.2015.08.003.

Sawant, A. A., Thakor, N. J., Swami, S. B., \& Divate, A. D. (2013). Physical and sensory characteristics of ready-to-eat food prepared from finger millet based composite mixer by extrusion. Agricultural Engineering International Journal, 15(1), 100-105. Retrieved from http://www. cigrjournal.org/index.php/Ejounral/article/view/2265/1704 
Serna-Saldivar, S. O. (2010). Cereal Grains. Properties, processing and nutritional attributes (pp. 538-562). USA: CRC Press.

Shahidi, F., \& Chandrasekara, A. (2013). Millet grain phenolics and their role in diseases risk reduction and health promotion - review. Journal of Functional Foods, 5(2), 570-581. http://dx.doi.org/10.1016/j. jff.2013.02.004.

Shibairo, S. I., Nyongesa, O., Onwonga, R., \& Ambuko, J. (2014). Variation of nutritional and anti-nutritional contents in finger millet (Eleusine coracana (L.) Gaertn) genotypes. Journal of Agriculture and Veterinary Science, 7(11), 6-11. http://dx.doi.org/10.9790/2380071110612. [Retrieved from http://www.iosrjournals.org/iosr-javs/ papers/vol7-issue11/Version-1/B071110612.pdf]

Shiihii, S. U., Musa, H., Bhati, P. G., \& Martins, E. (2011). Evaluation of physicochemical properties of Eleusine coracana starch. Nigerian Journal of Pharmaceutical Sciences, 10(1), 91-102.

Shimelis, A., Mulugela, T., \& Dawit, A. (2009). Chemical composition pf local and improved finger millet (Eleusine coracana L. Gaertn) varieties grown in Ethiopia. Ethiopian Journal of Health Sciences, 19(1), 1-18. Retrieved from https://www.ajol.info/index.php/ejhs/ issue/view/14822

Shimray, C. A., Gupta, S., \& Venkateswara Rao, G. (2012). Effect of native and germinated finger millet flour on rheological and sensory characteristics of biscuits. International Journal of Food Science \& Technology, 47(11), 2413-2420. http://dx.doi.org/10.1111/j.13652621.2012.03117.x.

Shobana, S., Krishnaswamy, K., Sudha, V., Malleshi, N. G., Anjana, R. M., Palaniappan, L., \& Mohan, V. (2013). Finger millet (Ragi, Eleusine coracana L.). Review of its nutritional properties, processing and plausible health benefits. Chapter 1. Advances in Food and Nutrition Research, 69, 1-39. http://dx.doi.org/10.1016/B978-0-12-4105409.00001-6. PMid:23522794.

Shukla, K., \& Srivastava, S. (2014). Evaluation of finger millet incorporated noodles for nutritive value and glycemic index. Journal of Food Science and Technology, 51(3), 527-534. http://dx.doi.org/10.1007/ s13197-011-0530-x. PMid:24587528.

Siddhart, M. (2014). Determination of physical characteristics of extruded snack food prepared using little millet (Panicum sumatranc) based composite flours. International Journal for Research in Applied Science and Engineering Technology, 2(7), 213-218. Retrieved from http://www.ijraset.com/fileserve.php?FID=659

Singer, C. S., Sabato, S. F., \& Tadini, C. C. (2006, April 26-28). Bread making properties of flour produced from irradiated wheat. In International Symposium on Future of Food Engineering. Warsaw, Poland: CIGR. Retrieved from http://www.cigr.org/Governance/ technical-sections-6.php

Singh, K. P., Mishra, A., \& Mishra, H. N. (2012). Fuzzy analysis of sensory attributes of bread prepared from millet-based composite flours. Food Science and Technology (Campinas), 48, 276-282. http:// dx.doi.org/10.1016/j.lwt.2012.03.026.

Singh, P., \& Raghuvanshi, S. (2012). Finger millet for food and nutritional security. African Journal of Food Science, 6(4), 77-84. http://dx.doi. org/10.5897/AJFSX10.010.

Siwela, M. (2009). Finger millet grains phenolics and their impact on malt and cookie quality (PhD thesis). Retrieved from http:// repository.up.ac.za/bitstream/handle/2263/28784/02chapter2. pdf? sequence $=3$ \&isAllowed $=y$

Siwela, M., Taylor, J. R. N., de Milliano, W. A. J., \& Duodu, K. G. (2007). Occurrence and location of tannins in finger millet grain and antioxidant activity of different grain type. Cereal Chemistry, 84(2), 169-174. http://dx.doi.org/10.1094/CCHEM-84-2-0169.
Sood, S., Kant, L., \& Pattnayak, A. (2017). Finger millet [Eleusine coracana (L.) Gaertn.]: a minor crop for sustainable food and nutrition. Mini Review. Asian Journal of Chemistry, 29(4), 707-710. http://dx.doi. org/10.14233/ajchem.2017.20284.

Sood, S., Komar, A., Babu, B. K., Gaur, V. S., Pandey, D., Kant, L., \& Pattnayak, A. (2016). Gene, discovery and advances in Finger millet [Eleusine coracana (L.) Gaertn.]. Genomics-An important nutricereal of future. Frontiers in Plant Science, 7, 1-17. http://dx.doi. org/10.3389/fpls.2016.01634.

Sripriya, G., Antony, U., \& Chandra, T. S. (1997). Changes in carbohydrate, free amino acids, organic acids, phytate and $\mathrm{HCl}$ extractability of minerals during germination and fermentation of finger millet (Eleusine coracana). Food Chemistry, 58(4), 345-350. http://dx.doi. org/10.1016/S0308-8146(96)00206-3.

Subastri, A., Ramamurthy, C., Suyavaran, A., Mareeswaran, R., Mandal, P., Rellegadla, S., \& Thirunavukkarasu, C. (2015). Nutrient profile of porridge made from Eleusine coracana (L.) grains: effect of germination and fermentation. Journal of Food Science and Technology, 52(9), 6024-6030. http://dx.doi.org/10.1007/s13197-015-1713-7.

Thapliyal, V., \& Singh, K. (2015). Finger millet: potential millet for food security and power house of nutrients. International or Research in Agriculture and Forestry, 2(2), 22-33. Retrieved from http://www. ijraf.org/pdf/v2-i2/4.pdf

Thilagavathi, T., Banumathi, P., Kanchana, S., \& Ilamaran, M. (2015). Effect of heat moisture treatment on functional and phytochemical properties of native and modified millet flours. Plant Archives, 15(1), 15-20. Retrieved from https://org/PDF\%2015\%20-\%201/15-21\%20 (2953).pdf

Towo, E., Mgoba, C., Ndossi, G. D., \& Kimboka, S. (2006). Effect of phytate and iron-binging phenolics on the content and availability of iron and zinc in micronutrients fortified cereal flours. African Journal of Food, Agriculture, Nutrition and Development, 6(2), 1-13.

Tripathi, B., \& Platel, K. (2010). Finger millet (Eleusine coracana) flour as a vehicle for fortification with zinc. Journal of Trace Elements in Medicine and Biology, 24(1), 46-51. http://dx.doi.org/10.1016/j. jtemb.2009.09.001. PMid:20122580.

Udeh, H. O., Doudu, K. G., \& Jideani, A. I. O. (2017). Finger millet bioactive compounds, bioaccessibility, and potential health effects - a review. Czech Journal of Food Sciences, 35(1), 7-17. http://dx.doi. org/10.17221/206/2016-CJFS.

Upadhyaya, H. D., Ramesh, S., Sharma, S., Singh, S. K., Varshney, S. K., Sarma, N. D. R. K., Ravishankar, C. R., Narasimhudu, Y., Reddy, V. G., Sahrawat, K. L., Dhanalakshmi, T. N., Mgonja, M. A., Parzies, H. K., Gowda, C. L. L., \& Singh, S. (2011). Genetic diversity for grains nutrients contents in a core collection of finger millet, Eleusine coracana L. germplasm. Field Crops Research, 121(1), 42-52. http:// dx.doi.org/10.1016/j.fcr.2010.11.017.

Usai, T., Nyamunda, B. C., \& Mutonhodza, B. (2013). Malt quality parameters of finger millet for brewing commercial opaque beer. International Journal of Science and Research, 2(9), 146-149. Retrieved from https://www.ijsr.net/archive/v2i9/MTIwMTMxMzk=.pdf

Vadivoo, A. S., Joseph, R., \& Ganesan, N. M. (1998). Genetic variability and calcium contents in finger millet (Eleusine coracana L. Gaertn) in relation to grain colour. Plant Foods for Human Nutrition (Dordrecht, Netherlands), 52(4), 353-364. http://dx.doi. org/10.1023/A:1008074002390. PMid:10426122.

van Wyk, B. E., \& Gericke, N. (2018). People's plants - a guide to useful plants of Southern Africa. A guide to useful plants of Southern Africa (2nd ed., pp. 405). Pretoria: Briza Publications. 
Retrieved from www.briza.co.za/catalog/product_info_php? Products_id $=324$

Vanithasri, J., Kanchana, S., Hemalatha, G., Vanniarajan, C., \& Sahulhameed, M. (2012). Role of millets and its importance in new mellinium. International Journal of Food Science \& Technology, 2(1), 35-47. Retrieved from http://www.tjprc.org/publishpapers/ tjprcfile342.pdf

Verma, V., \& Patel, S. (2013). Value added products from nutria-cereals, finger millet (Eleusine coracana). Emirates Journal of Food and Agriculture, 25(3), 169-176. http://dx.doi.org/10.9755/ejfa.v25i3.10764.
Wankhede, D. B., Shehnaj, A., \& Raghavendra Rao, M. R. (1979). Carbohydrate composition of finger millet (Eleusine coracana) and foxtail millet (Setaria Italica). Plant Foods for Human Nutrition (Dordrecht, Netherlands), 4(4), 293-303. http://dx.doi.org/10.1007/ BF01095511.

Wrigley, C. W., \& Batey, I. L. (2010). Cereal grains: assessing and managing quality. USA: CRC Press. .

Young, R. (1999). Finger miller processing in East Africa. Vegetation History and Archaeobotany, 8(1-2), 31-34. http://dx.doi.org/10.1007/ BF02042840. 